University of Nebraska - Lincoln

DigitalCommons@University of Nebraska - Lincoln

\title{
A comparison of complete mitochondrial genomes of silver carp Hypophthalmichthys molitrix and bighead carp Hypophthalmichthys nobilis: implications for their taxonomic relationship and phylogeny
}

S. F. Li

USGS Columbia Environmental Research Center, sfli@shou.edu.cn

J. W. Xu

Shanghai Ocean University

Q. L. Yang

Shanghai Ocean University

C. H. Wang

Shanghai Ocean University

Q. Chen

Shanghai Ocean University, wangch@shou.edu.cn

See next page for additional authors

Follow this and additional works at: https://digitalcommons.unl.edu/usgsstaffpub

Li, S. F.; Xu, J. W.; Yang, Q. L.; Wang, C. H.; Chen, Q.; Chapman, D. C.; and Lu, Guoqing, "A comparison of complete mitochondrial genomes of silver carp Hypophthalmichthys molitrix and bighead carp Hypophthalmichthys nobilis: implications for their taxonomic relationship and phylogeny" (2009). USGS Staff -- Published Research. 605.

https://digitalcommons.unl.edu/usgsstaffpub/605

This Article is brought to you for free and open access by the US Geological Survey at DigitalCommons@University of Nebraska - Lincoln. It has been accepted for inclusion in USGS Staff -- Published Research by an authorized administrator of DigitalCommons@University of Nebraska - Lincoln. 


\section{Authors}

S. F. Li, J. W. Xu, Q. L. Yang, C. H. Wang, Q. Chen, D. C. Chapman, and Guoqing Lu 


\title{
A comparison of complete mitochondrial genomes of silver carp Hypophthalmichthys molitrix and bighead carp Hypophthalmichthys nobilis: implications for their taxonomic relationship and phylogeny
}

\author{
S. F. LI ${ }^{\|} \dagger$, J. W. XU*, Q. L. YANG*, C. H. WANG*, Q. Chen*, D. C. \\ ChapMan† AND G. LU† \\ *Key Laboratory of Aquatic Genetic Resources and Utilization, Ministry of Agriculture, Shanghai \\ Ocean University, Shanghai, 200090, China, †USGS Columbia Environmental Research Center, \\ Columbia, MO 65201, U.S.A. and $\ddagger$ Department of Biology, University of Nebraska at Omaha, \\ Omaha, NE 68182, U.S.A.
}

(Received 24 April 2008, Accepted 3 March 2009)

\begin{abstract}
Based upon morphological characters, Silver carp Hypophthalmichthys molitrix and bighead carp Hypophthalmichthys nobilis (or Aristichthys nobilis) have been classified into either the same genus or two distinct genera. Consequently, the taxonomic relationship of the two species at the generic level remains equivocal. This issue is addressed by sequencing complete mitochondrial genomes of $H$. molitrix and $H$. nobilis, comparing their mitogenome organization, structure and sequence similarity, and conducting a comprehensive phylogenetic analysis of cyprinid species. As with other cyprinid fishes, the mitogenomes of the two species were structurally conserved, containing 37 genes including 13 protein-coding genes, two ribosomal RNA genes, 22 transfer RNA (tRNAs) genes and a putative control region (D-loop). Sequence similarity between the two mitogenomes varied in different genes or regions, being highest in the tRNA genes (98.8\%), lowest in the control region $(89.4 \%)$ and intermediate in the protein-coding genes (94.2\%). Analyses of the sequence comparison and phylogeny using concatenated protein sequences support the view that the two species belong to the genus Hypophthalmichthys. Further studies using nuclear markers and involving more closely related species, and the systematic combination of traditional biology and molecular biology are needed in order to confirm this conclusion.

(C) 2009 The Authors

Journal compilation (c) 2009 The Fisheries Society of the British Isles
\end{abstract}

Key words: bighead carp; generic taxonomy; mitochondrial genome; molecular phylogeny; sequence comparison; silver carp.

\section{INTRODUCTION}

According to the Linnaean taxonomic system, a genus is a low-level rank used to categorize a group of closely related species that descend from a common ancestor. Traditionally, the classification of species relies mainly on the characterization of

||Author to whom correspondence should be addressed. Tel.: +86 216190 0450; fax: +86 216190 0450; email: sfli@shou.edu.cn 
homologous morphological characters. Such characters, however, are lacking or not easy to identify in certain closely related groups. With the advent and application of molecular phylogeny, significant progress has been achieved in resolving some taxonomic questions, particularly when data from molecular biology are combined with data from traditional biology (Hedges \& Poling, 1999; Giribet et al., 2001; Saitoh et al., 2006). Successful examples in fishes have been reported, based on the analysis of complete mitochondrial genome sequences (Miya et al., 2003; Peng et al., 2006; Saitoh et al., 2006).

Silver carp Hypophthalmichthys molitrix (Valenciennes) and bighead carp Hypophthalmichthys nobilis (Richardson) belong to the family Cyprinidae. They were originally described as species of the genus Leuciscus and subsequently placed in the genus Hypophthalmichthys until Oshima (1919) reclassified H. nobilis to the genus Aristichthys. A set of morphological characters were developed to distinguish Aristichthys from Hypophthalmichthys, including gill raker morphology, position of the abdominal keel and pharyngeal dentition as well as pectoral-fin length. Consequently, some ichthyologists classified silver carp in the genus Hypophthalmichthys and bighead carp in Aristichthys (Cheng \& Zheng, 1987; Wu, 1964), whereas other ichthyologists placed both species in the genus Hypophthalmichthys (Howes, 1981; Kolar et al., 2007).

Hypophthalmichthys molitrix and H. nobilis are native to eastern Asia and have been broadly introduced to southern Asia, Europe and North America (Kolar et al., 2007). The two carps adapt to various environments very well and are widely distributed in the world. Their production in 2005 reached 3.52 and $2.18 \times 10^{6} \mathrm{t}$ in China and 4.15 and $2.21 \times 10^{6}$ t in the world, respectively (FAO, 2005). Because of their importance in aquaculture and in biological control of water quality, both species have been extensively studied in a variety of areas, including traditional biology (Li et al., 1997, 1998; Kolar et al., 2007), cytogenetics (Li, 1998), isoenzymes (Xia et al., 1996; Zhao \& Li, 1996; Jiang et al., 1998) and molecular genetics Fan et al., 1994; Lu et al., 1997, 2005; Jian \& Xia, 1999; Zhang et al., 1999a, b, 2001, 2002; Zhang, 2002; Geng et al., 2006; Shan et al., 2006; Zhu et al., 2007. To date, however, the complete mitochondrial genome, consisting of important evolutionary information, has not been sequenced in H. molitrix and H. nobilis .

In this study, the complete mitochondrial genomes of $H$. molitrix and $H$. nobilis are reported, the results of sequence comparison at the genome and gene levels are described, and the phylogeny of 53 cyprinid fishes using concatenated protein sequences is presented. In addition, issues pertaining to the taxonomic and phylogenetic relationships between the two species at the generic level are discussed.

\section{MATERIALS AND METHODS}

\section{SAMPLE COLLECTION AND DNA EXTRACTION}

Three samples of each species with body mass of 400-500 g were collected in the lower Yangtze River $\left(32^{\circ} 15^{\prime} \mathrm{N} ; 119^{\circ} 25^{\prime} \mathrm{W}\right)$ in 2005 . A small piece of the caudal fin from each sample was taken and stored in $95 \%$ ethanol. Whole genomic DNA, including mitochondrial DNA (mtDNA), was extracted using a proteinase $\mathrm{K}$ and phenol-chloroform procedure (Sambrock \& Russell, 2001). The quantity and quality of the extracted DNA were estimated on $1 \%$ agarose gels stained with ethidium bromide (EB). 


\section{PRIMER DESIGN，PCR AMPLIFICATION AND SEQUENCING}

Eighteen pairs of primers (Table I) were designed to amplify the complete mtDNA sequence of these two species, according to the alignment of reported complete mitogenome sequences of common carp Cyprinus carpio L., crucian carp Carrasius auratus (L.) and tench Tinca tinca (L.) (Chang et al., 1994; Murakami et al., 1998; Mabuchi et al., 2006; Saitoh et al., 2006). Polymerase chain reaction (PCR) was performed using an Eppendorf Thermal Cycler (www.eppendorf.com) within a reaction mixture of $50 \mu 1$ containing 2 units of Taq DNA polymerase (Tiangen Inc.; www.tiangen.com/eng), $5 \mu 110 \times$ PCR buffer (Tiangen Inc.), $50 \mathrm{ng} / \mu \mathrm{l}$ template DNA, $0.4 \mathrm{mM}$ each dNTP and $0.2 \mu \mathrm{M}$ each primer, in distilled water. The reaction was denatured at $94^{\circ} \mathrm{C}$ for $5 \mathrm{~min}$, followed by 30 cycles at $94^{\circ} \mathrm{C}$ for $30 \mathrm{~s}, 54^{\circ} \mathrm{C}$ for $30 \mathrm{~s}$ and $72^{\circ} \mathrm{C}$ for $1 \mathrm{~min}$; a final extension was done at $72^{\circ} \mathrm{C}$ for 10 min. All amplified products were purified using a $3 \mathrm{~S}$ Spin PCR Product Purification Kit (Biocolor Inc.; www.biocolor-online.com) following the supplier's instructions. The purified products were sequenced on an Applied Biosystems ABI 3730 capillary sequencer (www.appliedbiosystems.com).

\section{SEQUENCE ASSEMBLY AND GENE IDENTIFICATION}

DNA sequences were examined using the basic local alignment search tool (BLAST) search tool available at the NCBI website (www.ncbi.nlm.nih.gov) to make sure that the correct DNA targets were amplified. The BioEdit 7.0 package was then used to edit and assemble mtDNA sequences for the complete genomes of these two species (Hall, 1998). tRNA genes were identified using tRNAscan-SE 1.21 (Lowe \& Eddy, 1997) with the following settings: (1) default search mode, (2) mitochondrial-chloroplast DNA as the source and (3) vertebrate mitochondrial genetic code for tRNA structure prediction. Protein and ribosomal RNA genes were determined based on sequence similarity as compared with C. carpio, C. auratus and T. tinca. The $5^{\prime}$-end of the protein-coding genes was inferred using start codons ATG, GTG, TTG and GTT whereas the $3^{\prime}$-end termini were inferred using the stop codons TAA, TAG, AGA and AGG.

Protein-coding genes are commonly more informative in inferring species phylogeny (Peng et al., 2006). Mitochondrial protein sequences of 53 cyprinid species were thus retrieved from the NCBI Genome database for the phylogenetic analysis. The concatenated protein sequences of 13 genes were aligned using MUSCLE (Edgar, 2004). Excluding H. molitrix and $H$. nobilis, the remaining 51 cyprinid species were divided into two groups, i.e. intrageneric and intergeneric, to evaluate their taxonomic relationships at the generic level. The JTT model, based on a recounting of the number of observed changes in amino acids (Jones et al., 1992), was used to calculate genetic distances of pairwise sequences under MEGA 4.0 (Tamura et al., 2007). Phylogenetic analyses were performed using neighbour-joining (NJ) in MEGA, maximum likelihood (ML) in Multiphyl (Keane et al., 2007), and Bayesian Markov-ChainMonte-Carlo (MCMC) method in MrBayes 3.1.2 (Ronquist \& Huelsenbeck, 2003). Based on tests of 88 amino acid substitution models, MtMam $+\mathrm{I}+\mathrm{G}+\mathrm{F}(-\operatorname{lnL}=49935.9755$, Gamma distribution parameter $a=0.59$, invariable sites Pinv $=0.58$ ) were selected for the ML analyses of concatenated mitochondrial protein sequences. Two million generations with four chains were run for Bayesian analysis and the trees sampled prior to reaching convergence were discarded before computing the consensus tree and posterior probabilities. Two independent runs were used to provide additional confirmation of the convergence of the posterior probability distribution. Bootstrap values and posterior probabilities were used to evaluate the above phylogenetic trees. 


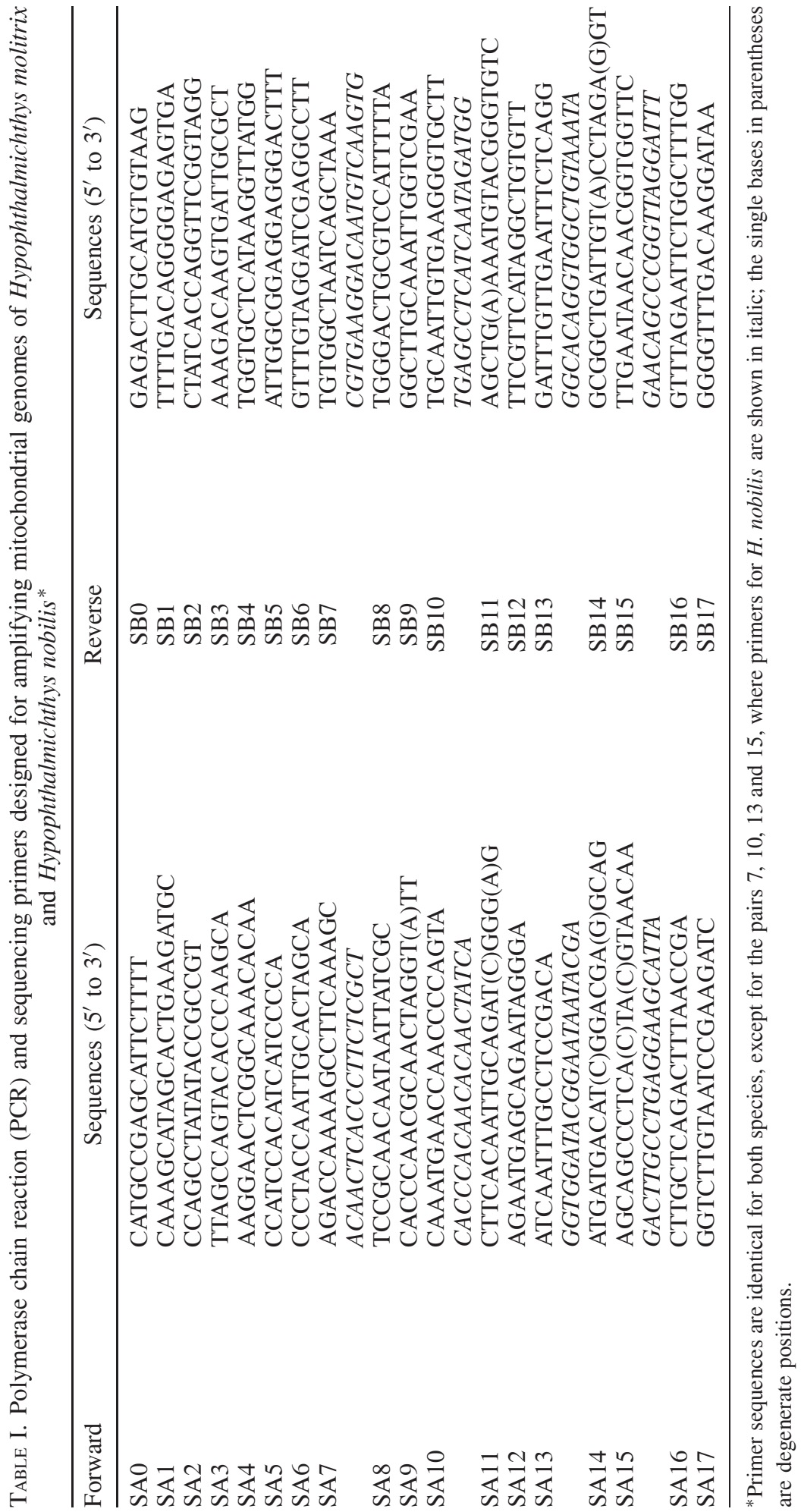




\section{RESULTS}

\section{MITOCHONDRIAL GENOME ORGANIZATION AND COMPOSITION}

The mitochondrial genomes of $H$. molitrix and $H$. nobilis are similar to those of other cyprinids (Fig. 1). The size of the complete genome is $16620 \mathrm{bp}$ for H. molitrix and 16621 bp for $H$. nobilis. Both species contain 13 proteincoding genes (Cytb, ATP6, ATP8, COI to III, ND1 to 6, ND4L), 22 transfer RNA genes, two ribosomal RNA genes (12S rRNA and 16S rRNA) and a putative control region (Table II). Overlaps between adjacent genes were found in both species, as revealed in other cyprinids. The overall base composition of the mitochondrial genomes is highly similar between these two species: $\mathrm{A}=$ $31.8 \%, \mathrm{C}=26.9 \%, \mathrm{G}=15.7 \%, \mathrm{~T}=25.6 \%, \mathrm{~A}+\mathrm{T}=57.4 \%$ in H. molitrix; $\mathrm{A}=$ $31.6 \%, \mathrm{C}=27 \cdot 1 \%, \mathrm{G}=16 \cdot 0 \%, \mathrm{~T}=25.3 \%, \mathrm{~A}+\mathrm{T}=56.9 \%$ in $H$. nobilis (Fig. 2). Overall nucleotide sequence similarity between the two mitochondrial genomes is $95 \cdot 1 \%$.

\section{PROTEIN-CODING GENES}

As with other cyprinids, protein-coding genes of the mitochondrial genome in $H$. molitrix and $H$. nobilis contain the strand start codon ATG except the gene COI, which contains GTG instead. The open reading frames (ORF) for the protein-coding genes are terminated using TAA (ND1, COI, ATPase8, ATPase6, COIII, ND4L, ND5 and ND6), TAG (ND2 in H. molitrix, ND2 to 4 in H. nobilis) and incomplete stop codon T- (COII and Cytb in H. molitrix; ND1, COII and Cytb in H. nobilis). Incomplete stop codons were observed commonly in the protein-coding genes of teleost mitochondria (Peng et al., 2006; Kartavtsev et al., 2007). Of the 13 proteincoding genes, 12 are encoded on the H-strand of the mtDNA whereas only the ND6 gene is encoded on the L-strand (Table II).

Three reading-frame overlaps were observed in mitochondrial genomes of the two species. In H. molitrix one nucleotide overlaps between ATP6 and COIII whereas 10 nucleotides overlap between ATP8ase and ATP6ase, and seven between ND4 and ND4L. In H. nobilis only seven nucleotides overlap between ATPase8 and ATPase6, and the other two overlaps are the same as in $H$. molitrix. The total length of the 13 protein-coding genes is $11431 \mathrm{bp}$ for $H$. molitrix, accounting for $68.78 \%$ of the whole mitogenome and 11429 bp for $\mathrm{H}$. nobilis, which accounts for $68.76 \%$ of the whole mitogenome. Both species contain nucleotide $G$ least frequently in the third codon position. Nucleotide sequence similarity between mitochondrial protein-coding genes of both species is $94.2 \%$.

\section{NON-CODING SEQUENCE}

The length of the major non-coding (D-loop) region, located between tRNA ${ }^{\text {Pro }}$ and tRNA ${ }^{\text {Phe }}$, is $936 \mathrm{bp}$ in H. molitrix and $938 \mathrm{bp}$ in H. nobilis, respectively. As with other fish species (Kartavtsev et al., 2007), the D-loop region can be divided into three domains. The first domain is hypervariable and consists of a terminationassociated sequence (TAS: TACATATGTA in H. molitrix; TAS: TACAT AAT GTA CTA ATA CCT ATA TATGTATTAT in $H$. nobilis $)$. The second domain is the central 

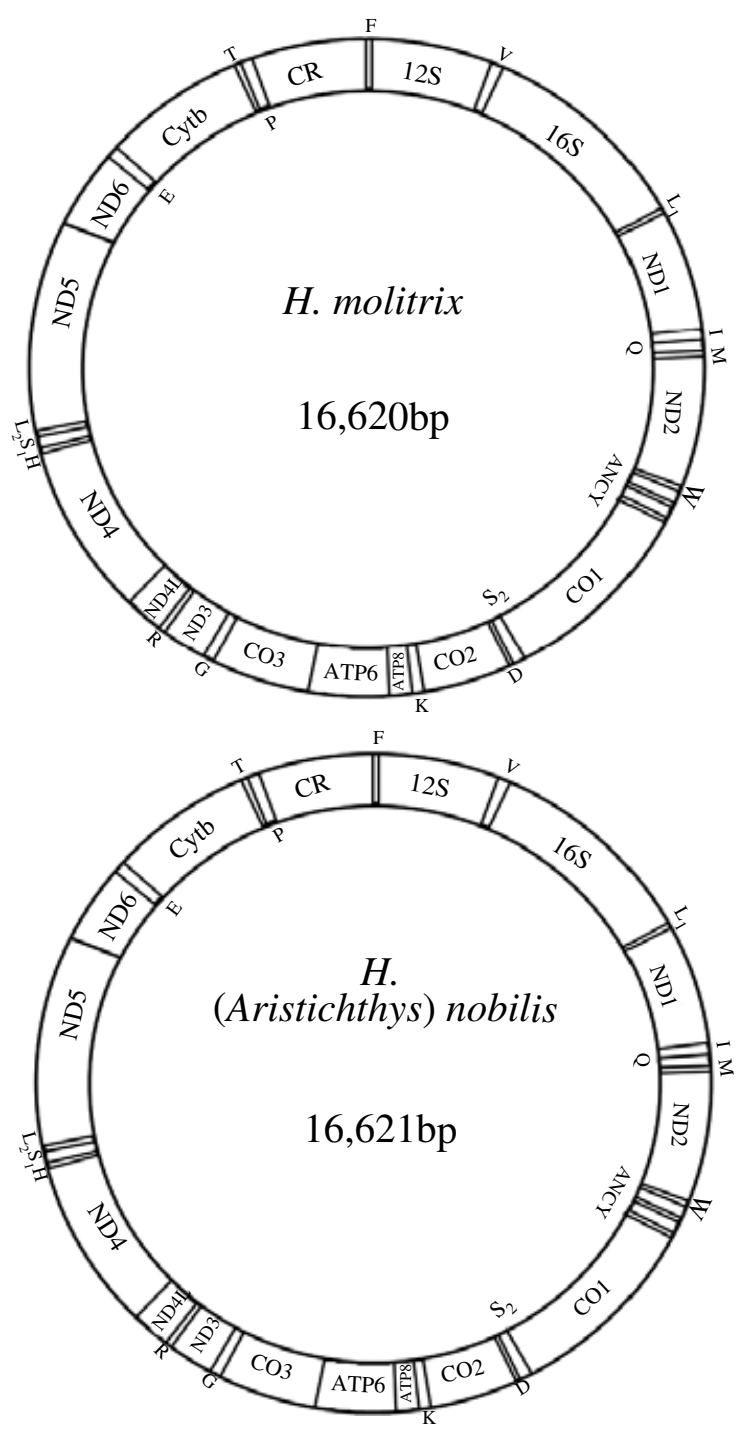

FIG. 1. The mitochondrial genomes of Hypophthalmichthys molitrix and Hypophthalmichthys (Aristichthys) nobilis. L-strand is designated on the inside and $\mathrm{H}$-strand on the outside of the molecule. 12S and $16 \mathrm{~S}$, genes of the $12 \mathrm{~S}$ and $16 \mathrm{~S}$ ribosomal RNA; ND1-6 and $4 \mathrm{~L}$, nicotinamide adenine dinucleotidede hydrogenase subunits 1-6 and 4 L; COI-III, cytochrome $c$ oxidase subunits I-III; ATP6 and ATP8, ATPase subunits 6 and 8; cyt $b$, cytochrome $b$; CR, control region; tRNAs are designated by single-letter amino acid codes except leucine and serine, which are labelled as $\mathrm{L}_{1}\left(\mathrm{tRNA}^{\mathrm{Leu}(\mathrm{UUR})}\right), \mathrm{L}_{2}\left(\mathrm{tRNA}^{\mathrm{Leu}(\mathrm{CUN})}\right)$, $\mathrm{S}_{1}\left(\mathrm{tRNA}^{\mathrm{Ser}(\mathrm{AGN})}\right)$ and $\mathrm{S}_{2}\left(\mathrm{tRNA}^{\mathrm{Ser}(\mathrm{UCN})}\right)$.

conserved region with $375-575 \mathrm{bp}$. The third domain consists of three conserved blocks (CSB-1, CSB-2, and CSB-3) and contains a TA-dinucleotide microsatellite repeat. Sequence similarity between D-loop regions of both species is $89.4 \%$. 


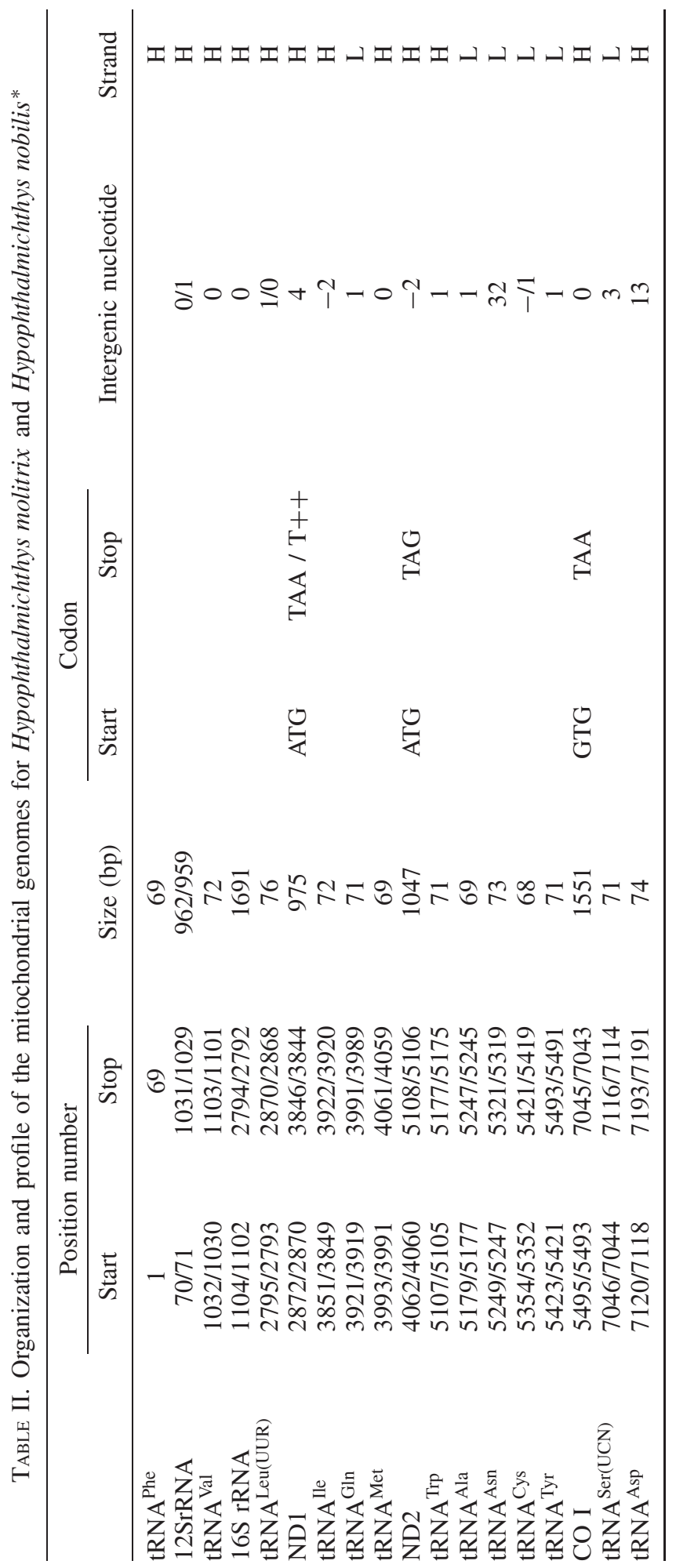




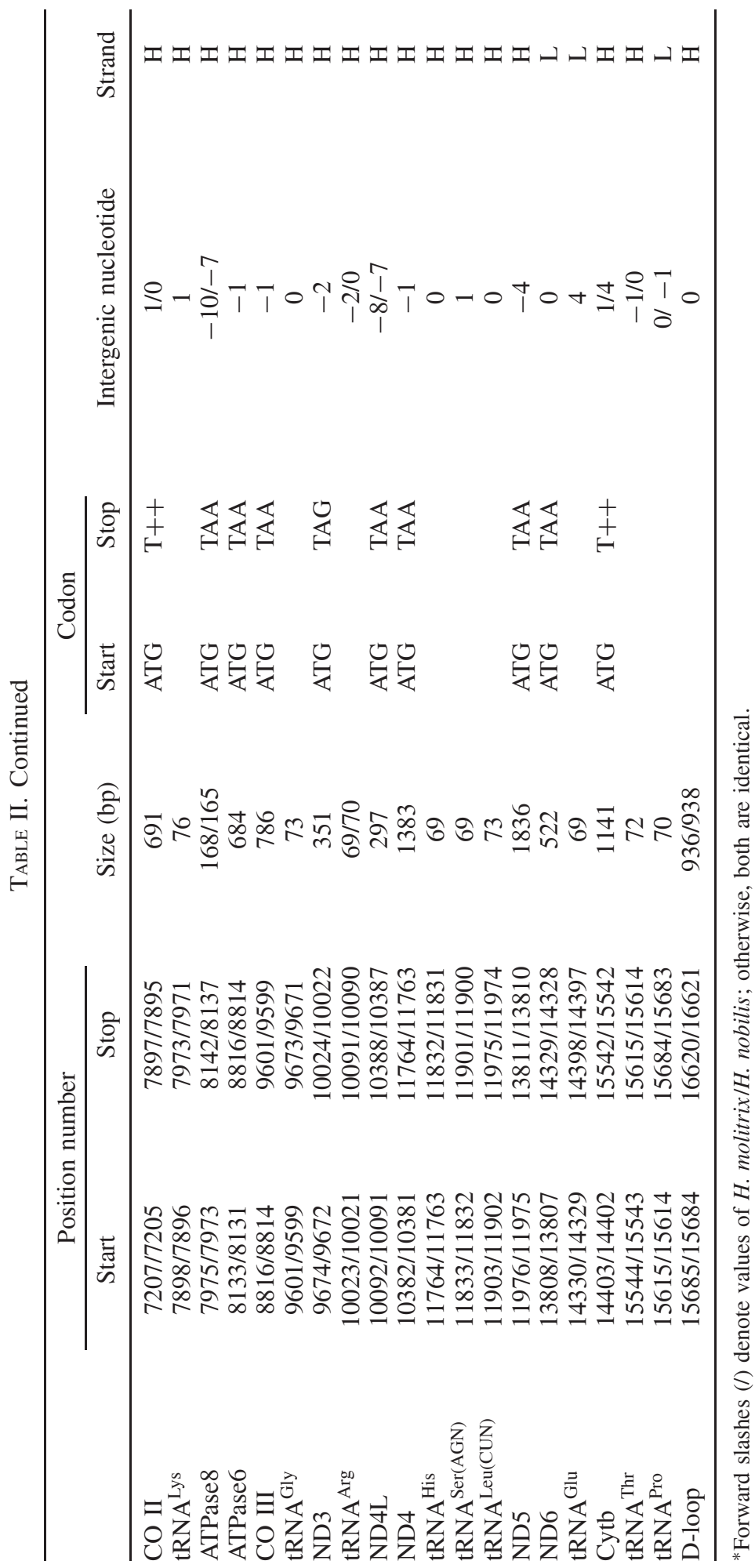




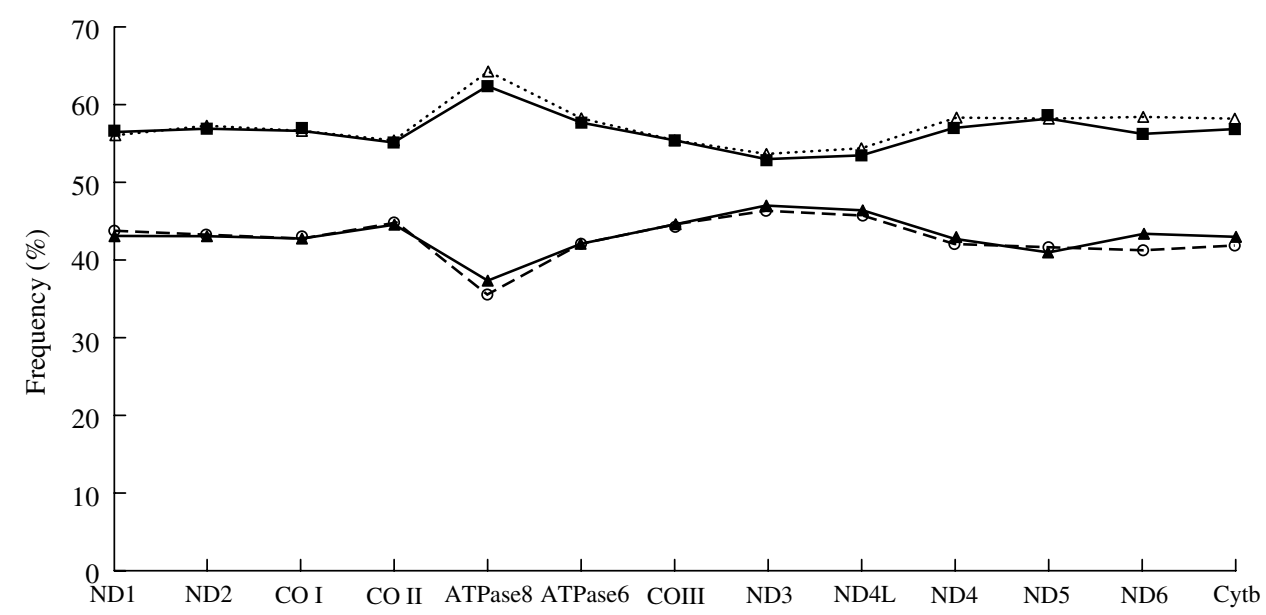

FIG. 2. Comparison of base composition in the mitochondrial protein-coding genes between Hypophthalmichthys molitrix $[\mathrm{A}+\mathrm{T}(\cdots \Delta \cdots)$ and $\mathrm{C}+\mathrm{G}(--\mathrm{O}--)]$ and Hypophthalmichthys nobilis $[\mathrm{A}+\mathrm{T}$ $(\longrightarrow$ ) and $\mathrm{C}+\mathrm{G}(\longrightarrow-)$.

In both $H$. molitrix and $H$. nobilis, a small non-coding region of $42 \mathrm{bp}$, the putative origin of light strand replication $\left(\mathrm{O}_{\mathrm{L}}\right)$, is located in a cluster of $\mathrm{tRNA}^{\mathrm{Trp}}-\mathrm{tRNA}^{\mathrm{Ala}}-\mathrm{tRNA}^{\mathrm{Asn}}-\mathrm{tRNA}^{\mathrm{Cys}}-\mathrm{tRNA}^{\mathrm{Tyr}}$ region (ie. the WANCY region, a hot spot for gene order rearrangements). This region has the potential to fold into a stable stem-loop secondary structure with $19 \mathrm{bp}$ in the stem and $11 \mathrm{bp}$ in the loop. The conserved motif $5^{\prime}-\mathrm{GCCGG}-3^{\prime}$, located at the bottom of the tRNA ${ }^{\text {Cys }}$ stem is regarded to be associated with the transition from RNA synthesis to DNA synthesis, (Hixson et al., 1986).

\section{RIBOSOMAL AND TRANSFER RNA GENES}

The mitochondrial genomes of $H$. molitrix and $H$. nobilis contain two subunits of ribosomal RNA, a small one (12S) and a large one (16S). These two subunits are separated by tRNA ${ }^{\text {Val }}$. The length of the $12 \mathrm{~S}$ rRNA gene is $962 \mathrm{bp}$ for H. molitrix and 949 bp for H. nobilis. This length is similar in other fish species (Chang et al., 1994; Murakami et al., 1998; Guo et al., 2006; Mabuchi et al., 2006). The 16S rRNA gene has the same length (1691 bp) in both $H$. molitrix and H. nobilis. Length variation has been, however, found in other species such as T. tinca, C. carpio and C. auratus (Chang et al., 1994; Murakami et al., 1998; Guo et al., 2006; Mabuchi et al., 2006). The average sequence similarity of mitochondrial rRNA genes between the two species is $98.6 \%$.

Twenty-two tRNA genes are interspersed by the rRNA and protein-encoding genes and their lengths range from 68 to $76 \mathrm{bp}$. There are overlaps between adjacent tRNA genes, e.g. one nucleotide overlapping between $\mathrm{tRNA}^{\mathrm{Thr}}$ and $\mathrm{RNA}^{\text {Pro }}$, two between tRNA $^{\text {Ile }}$ and tRNA ${ }^{\text {Gln }}$ and three between tRNA ${ }^{\text {Cys }}$ and tRNA ${ }^{\mathrm{Tyr}}$. The average A+T content of tRNAs is $56.1 \%$ for $\mathrm{H}$. molitrix and $55.8 \%$ for $\mathrm{H}$. nobilis, respectively. These values are higher than those for rRNA genes (54.9\% in H. molitrix and $54.7 \%$ in $H$. nobilis), but lower than those for the D-loop region $(68.5 \%$ in $H$. molitrix and 
$67.4 \%$ in $H$. nobilis) (Table III). Sequence similarity between tRNA genes for the two species was $98.8 \%$ on average.

\section{TAXONOMIC AND PHYLOGENETIC ANALYSIS OF H. MOLITRIX AND H. NOBILIS}

The JTT distance estimated based on mitochondrial protein sequences between H. molitrix and H. nobilis is 0.009. The intrageneric JTT distance for 19 species that belong to eight genera (Barbus, Carassius, Cyprinella, Hemibarbus, Labeo, Opsariichthys, Puntius and Rhodeus) was estimated to be 0.063 on average, ranging from 0.003 to 0.193 . In terms of intergeneric analysis, the distance for 32 species that belong to distinct cyprinid genera was estimated to be 0.093 on average, ranging from 0.01 to 0.288 . The genetic distances among 51 species suggest that $H$. molitrix and $H$. nobilis be placed in the same genus. The ML phylogenetic tree of 53 cyprinids reveals that the number of amino acid substitutions, as denoted by branch length between $H$. molitrix and $H$. nobilis, is relatively small compared with species that belong to different cyprinid genera [Fig. 3(a)]. In addition, the monophyletic relationship between these two carps is highly supported by the bootstrap values as well as the Bayesian posterior probabilities [Fig. 3(b)].

\section{DISCUSSION}

In this study, the mitochondrial genomes of $H$. molitrix and $H$. nobilis were revealed to comprise the same number of genes and have an identical structure. This is consistent with the observations that most animal mitochondrial genomes contain the same 37 genes and that the gene order is highly conserved among vertebrates (Broughton et al., 2001). There was only 1 bp difference found between the two mitogenomes, with the whole length close to those of other fish species (Chang et al., 1994; Murakami et al., 1998; Broughton et al., 2001; Wang et al., 2008). Both mitogenomes contain a number of overlaps between adjacent genes,

TABLE III. Base composition (\%) of mitochondrial genes (or regions) for Hypophthalmichthys molitrix and Hypophthalmichthys nobilis

\begin{tabular}{lccccc}
\hline & \multicolumn{5}{c}{ Gene/fragment* } \\
\cline { 2 - 6 } Genes(regions) & $\mathrm{A}$ & $\mathrm{C}$ & $\mathrm{G}$ & $\mathrm{T}$ & $\mathrm{A}+\mathrm{T}$ \\
\hline Protein coding & $31.1 / 30.8$ & $28.5 / 28.6$ & $14.3 / 14.5$ & $26.1 / 26.0$ & $57.2 / 56.8$ \\
First & $29.1 / 28.7$ & $26.8 / 26.8$ & $23.6 / 23.9$ & $20.5 / 20.6$ & $49.6 / 49.3$ \\
Second & $20.1 / 20.1$ & $27.5 / 27.5$ & $13.7 / 13.7$ & $38.7 / 38.8$ & $58.8 / 58.9$ \\
Third & $44.1 / 43.6$ & $31.2 / 31.6$ & $5.5 / 6.1$ & $19.2 / 18.7$ & $63.3 / 62.3$ \\
tRNA & $30.5 / 30.3$ & $24.2 / 24.3$ & $19.7 / 19.9$ & $25.6 / 25.5$ & $56.1 / 55.8$ \\
srRNA & $34.8 / 34.8$ & $24.3 / 24.2$ & $20.8 / 21.1$ & $20.1 / 19.9$ & $54.9 / 54.7$ \\
D-loop & $34.2 / 35.4$ & $18.6 / 20.6$ & $12.9 / 12.0$ & $34.3 / 32.0$ & $68.5 / 67.4$ \\
Overall & $31.8 / 31.6$ & $26.9 / 27.1$ & $15.7 / 16.0$ & $25.6 / 25.3$ & $57.4 / 56.9$ \\
\hline
\end{tabular}

*Values of H. molitrix/H. nobilis. 
indicating the high efficiency in RNA transcription and protein translation (Anderson et al., 1981). In protein-coding genes, a strong bias (c. $6 \%$ ) against $\mathrm{G}$ has been observed in both carps as well as other vertebrates (Broughton et al., 2001). The control region is involved in the regulation of replication and transcription (Clayton, 1982, 1991; Shadel \& Clayton, 1997). In H. molitrix and H. nobilis, extensive variability was found in the control region, but several regulatory elements were conserved, demonstrating that the secondary or the tertiary structures rather than the primary structure (i.e. sequence) are important in regulating RNA transcription and DNA replication.

One of the salient features in this study is to explore the boundary of genetic divergence at the genus level. Concatenated protein sequences of the two carps as well as 19 intrageneric and 32 intergeneric cyprinid species were analysed. The genetic distance between $H$. molitrix and H. nobilis (0.009) is below the smallest distance estimated among the intergeneric species $(0.01$ between Chanodichthys mongolicus (Basilewsky) and Megalobrama amblycephala Yih, but within the genetic distances among intrageneric species (0.003-0.193). This provides the first molecular evidence in support of classifying silver and bighead carps in the same genus, i.e. Hypophthalmichthys. From the viewpoint of reproductive isolation, $H$. molitrix and $H$. nobilis are genetically closely related to each other. In portions of the introduced ranges of $H$. molitrix and $H$. nobilis, it has been observed that the two species can hybridize and produce fertile offspring (Verigin et al., 1979; Kolar et al., 2007; Chapman et al., in press). This would partially support placement of $H$. molitrix and $H$. nobilis in the same genus. There are a great number of cases, however, where hybridization occurs between species from different genera (Scribner et al., 2001).

In addition, there is a great deal of information that seems to support the viewpoint of placing $H$. molitrix and $H$. nobilis into two different genera. Besides the work by Oshima (1919), a series of previous studies revealed significant differences in ecological, biological and biochemical, as well as molecular characteristics between $H$. molitrix and H. nobilis (Li et al., 1997, 1998). For example, the native range of $H$. molitrix extends approximately from 20 to $54^{\circ} \mathrm{N}$, covering the Red River (northern Vietnam), Zhujiang (Pearl) River (southern China) and north to the Heilongjiang (Amur) River (the China-Russia border); the native range of $H$. nobilis is more narrow, approximately from 21 to $40^{\circ} \mathrm{N}$, covering the Zhujiang River north to the Huanghe (Yellow) River (northern China), but not to the Heilongjiang River (Li, 1996). The karyotypes also differ: H. molitrix has the karyotype $10 \mathrm{~m}+9 \mathrm{sm}+5 \mathrm{st}$, while $H$. nobilis has the karyotype $12 \mathrm{~m}+9 \mathrm{~m}+3$ st. They also differ in isozyme electrophoresis patterns. For instance, the relative activity of A1, A2B1, A2B2, A1B3 and $\mathrm{B} 4$ of $\mathrm{LDH}$ in muscle is $45 \cdot 0,32 \cdot 3,18 \cdot 6,2 \cdot 8$, and $1.4 \%$ in H. molitrix, but $54 \cdot 1$, 26.0, 15.9, 2.0, and $1.9 \%$ in H. nobilis (National Inspection Bureau for Quality and Technology, People's Republic China, 1999a, $b$ ). Chapman et al. (in press) recently identified 22 different morphometric ratios that were significantly different between H. molitrix and H. nobilis. For five of the ratios, the range of observed values did not overlap between the two species in a comparison of $>100$ fish of each species.

One major concern pertaining to the use of mtDNA in resolving phylogeny is that the entire mitogenome is essentially a single locus; linkage of all mitochondrial genes might increase systematic errors, e.g. compositional biases (Gadagkar et al., 


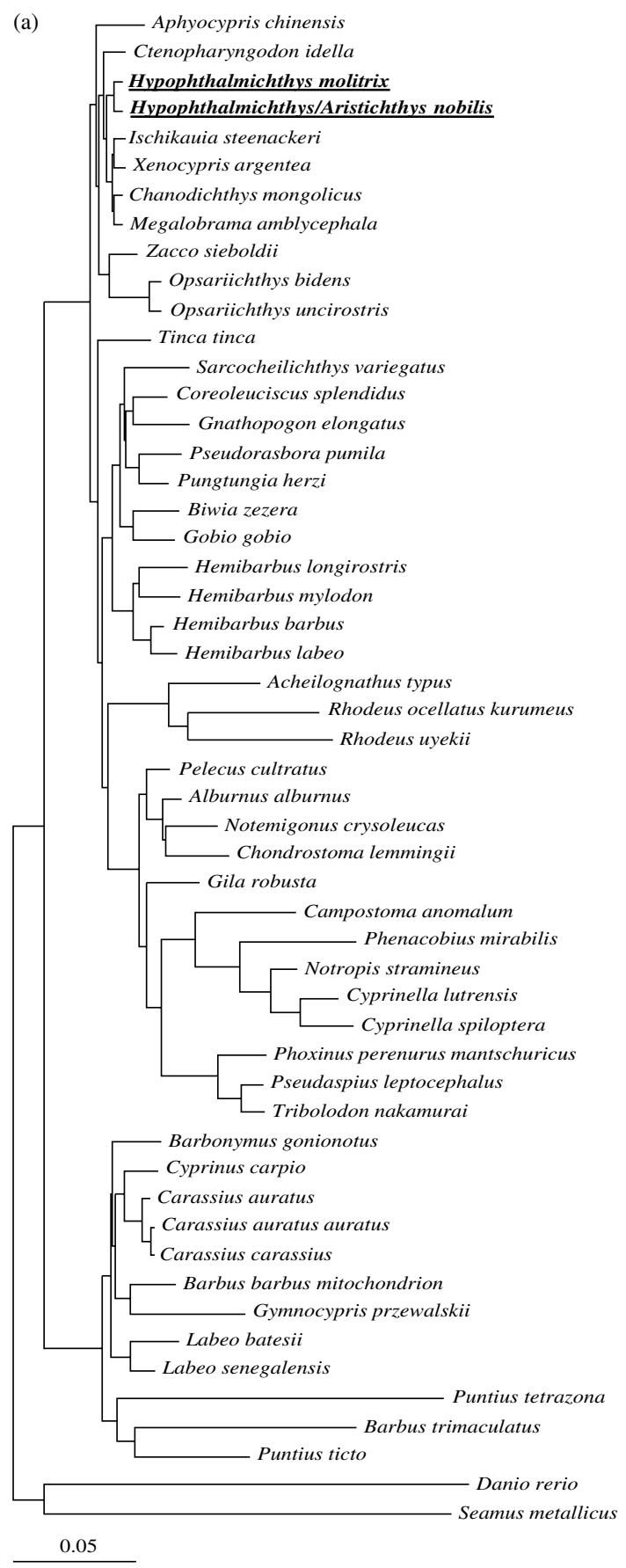

FIG. 3. Maximum likelihood (ML) phylogenetic trees of 53 cyprinid fishes; including Hypophthalmichthys molitrix and Hypophthalmichthys nobilis inferred from concatenated mitochondrial protein sequences. (a) Neighbour-joining (NJ) tree with branches scaled by 0.05 substitution per site and (b) majority rule tree $(50 \%)$ with the numbers representing bootstrap values from the $\mathrm{NJ}$ and ML analyses and posterior probabilities from the Bayesian analysis, respectively. 
(b)

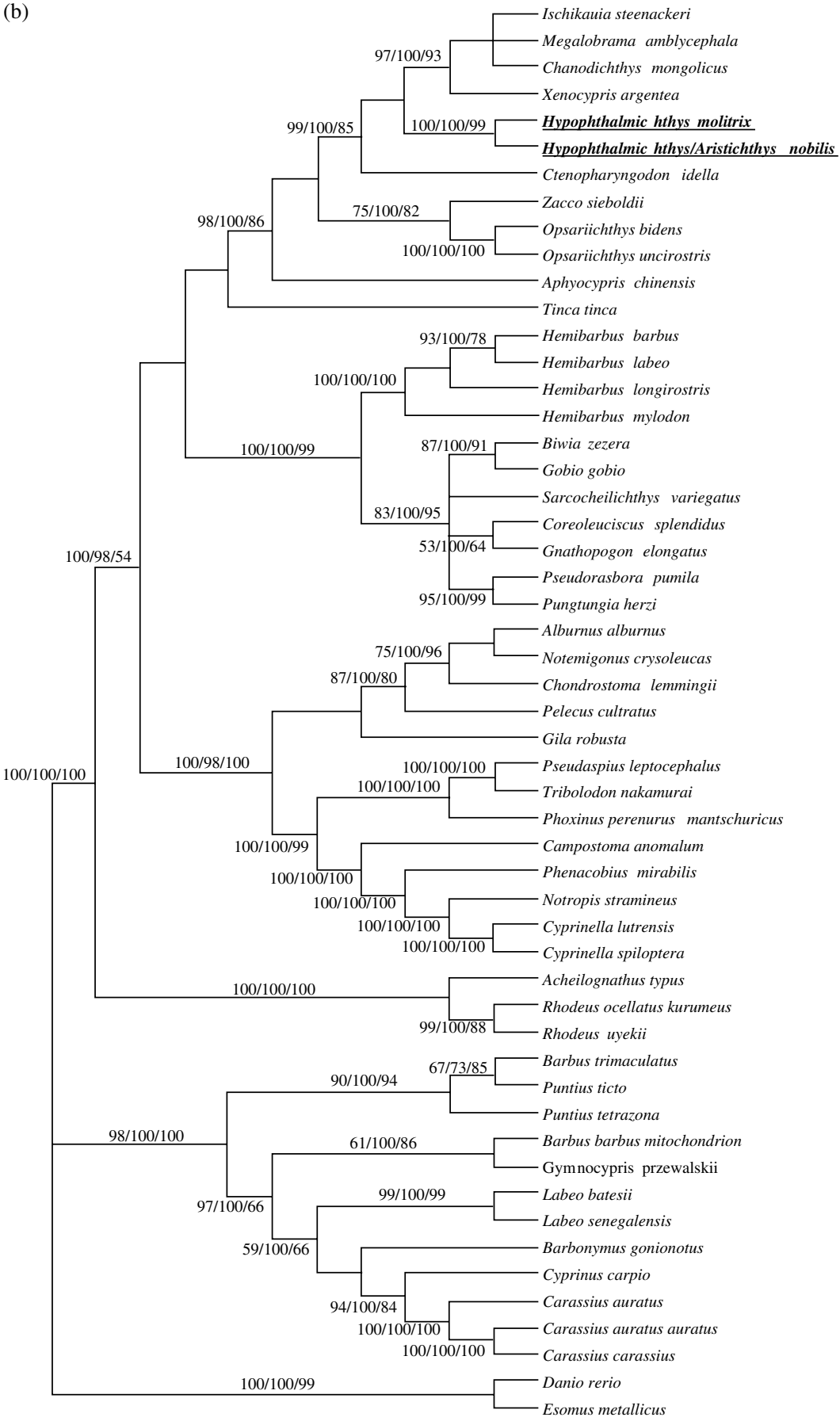

FIG. 3. Continued. 
2005). A more robust strategy is therefore to use combined datasets of complete mitogenomes and nuclear genes for the study of species phylogeny (Miya et al., 2007). In addition, another species, large-scale silver carp Hypophthalmicthys harmandi Sauvage is native to the Red River of northern Vietnam and the Hainan Island of southern China and is closely related to $H$. molitrix. Therefore, in order to attain a unified taxonomy for $H$. molitrix and $H$. nobilis at the generic level, more molecular markers such as nuclear genes, more closely related species such as $H$. harmandi, and systematic combination between traditional biological and molecular biological studies are required for further investigations in the future.

The authors would like to thank M. Tang and L. Fu (Hangjiang Chinese Farmed Fish Farm, China) for their kind help in collecting silver carp samples, C. Li (University of Nebraska-Lincoln, U.S.A.) for his help with revising the manuscript, and M. Christman (University of Nebraska at Omaha, U.S.A.) for proof reading the final draft of this paper. This research was supported by the National Natural Science Foundation of China (Grant No. 30630051) and the Shanghai Leading Academic Discipline Project (Grant No. Y1101).

\section{References}

Anderson, S., Bankier, A. T., Barrell, B. G., de Bruijin, M. H. L., Coulson, A. R., Drouin, J., Eperon, I. C., Nierlich, C. D. P., Roe, B. A., Sanger, F., Schreier, P. H., Smith, A. J. H., Staden, R. \& Young, I. G. (1981). Sequence and organization of the human mitochondrial genome. Nature 290, 457-65.

Broughton, R. E., Milam, J. E. \& Roe, B. A. (2001). The complete sequence of the zebrafish (Danio rerio) mitochondrial genome evolutionary patterns in vertebrate mitochondrial DNA. Genome Research 11, 1958-1967.

Chang, Y. S., Huang, F. L. \& Lo, T. B. (1994). The complete nucleotide sequence and gene organization of carp (Cyprinus carpio) mitochondrial genome. Journal of Molecular Evolution 38, 138-155.

Chapman, D. C., Deters, J. E. \& King, T. (in press). Occurrence of bighead carp X silver carp hybrids in the Missouri River, and an examination of morphological methods for determination of hybridization and sex. In Proceedings of the Asian Carp Symposium (Chapman, D. C. \& Hoff, M., eds). Bethesda, MD: American Fisheries Society.

Cheng, Q. T. \& Zheng, B. S. (1987). Systematic Synopsis of Chinese Fishes Beijing, China: Science Press (in Chinese).

Clayton, D. A. (1982). Replication of animal mitochondrial DNA. Cell 28, 693-705.

Clayton, D. A. (1991). Nuclear gadgets in mitochondrial DNA replication and transcription. Trends in Biochemical Sciences 16, 107-111.

Edgar, R. C. (2004). MUSCLE: multiple sequence alignment with high accuracy and high throughput. Nucleic Acids Research 32, 1792-1797.

FAO (2005). Yearbook of Fishery Statistics 2005-Aquaculture Production. Rome, Italy: Food and Agriculture Organization.

Fan L. C., Cui, J. X. \& Yu, Q. X. (1994). Restriction endonuclease map of mtDNA of Aristichthys nobilis. Journal of Wuhan University (Natural Science Edition) 40, 121-125 (in Chinese).

Gadagkar, S. R., Rosenberg, M. S. \& Kumar S. (2005). Inferring species phylogenies from multiple genes: concatenated sequence tree versus consensus gene tree. Journal of Experimental Zoology B 304, 64-74.

Geng, B., Sun, X. W., Lian, L. Q., Ouyang, H. S. \& Tong, J. G. (2006). Microsatellite analysis of genetic diversity of Aristichthys nobilis in China. Hereditas (Beijing) 28, 683-688 (in Chinese).

Giribet, G., Edgecombe, G. D. \& Wheeler W. C. (2001). Arthropod phylogeny based on eight molecular loci and morphology. Nature 413, 157-161. 
Guo, X., Liu, S. \& Liu, Y. (2006). Evidence for recombination of mitochondrial DNA in triploid crucian carp. Genetics 172, 1745-1749.

Hall, T. A. (1998). BioEdit: A user-friendly biological sequence alignment editor and analysis program for Windows 95/98/NT. Nucleic Acid Symposium Series 41, 95-98.

Hedges, S. B. \& Poling, L. L. (1999). A molecular phylogeny of reptiles. Science 283, $998-1001$.

Hixson, J. E., Wong, T. W. \& Clayton, D. A. (1986). Both the conserved and divergent 5'flanking sequences are required for initiation at human mitochondrial origin of light strand replication. Journal of Biological Chemistry 261, 2384-2390.

Howes, G. (1981). Anatomy and phylogeny of the Chinese major carps Ctenopharyngodon Steind., 1866 and Hypophthalmichthys Blkr., 1980. Bulletin of the British Museum of Natural History and Zoology 41, 1-52.

Jian, J. C. \& Xia, D. Q. (1999). Cloning of minisatellite DNA from bighead carp. Journal of Fishery Science of China 6, 18-20 (in Chinese).

Jiang, J. G., Xiong, Q. W. \& Yao, R. H. (1998). Comparative studies on isoensymes of black carp, grass carp, silver carp and bighead carp. Hereditas (Beijing) 20, 19-22 (in Chinese).

Jones, D. T., Taylor, W. R. \& Thornton, J. M. (1992). The rapid generation of mutation data matrices from protein sequences. CABIOS 8, 275-282.

Kartavtsev, Y. P., Jung, S. O., Lee, Y. M., Byeon, H. K. \& Lee, J. S. (2007). Complete mitochondrial genome of the bullhead torrent catfish, Liobagrus obesus (Siluriformes, Amblycipididae): Genome description and phylogenetic considerations inferred from the Cytb and 16S rRNA genes. Gene 396, 13-27.

Keane, T. M., Naughton, T. J. \& McInerney, J. O. (2007). MultiPhyl: a high-throughput phylogenomics webserver using distributed computing. Nucleic Acids Research 35, $33-37$.

Kolar, C. S., Chapman, D. C., Courtenay, W. R., Housel, C. M., Williams, J. D. \& Jennings, D. P. (2007). Bigheaded carps, a biological synopsis and environmental risk assessment. American Fisheries Society Special Publication 33.

Li, S. F. (1996). Germplasm Resources and Conservation of Freshwater Fishes in China. Beijing, China: China Agriculture Press (in Chinese).

Li, S. F., Zhou, B. Y., Lu, G. Q., Zhao, J. L, Yao, D. X. \& Shen, W. K. (1997). A study on the criteria and inspection of brooders of silver carp, bighead carp, grass carp and black carp originated from the Yangtze River. Journal of Fisheries of China 21, 143-151 (in Chinese).

Li, S. F. (Ed.) (1998). Genetic Characterization of Major Freshwater Culture Fishes in China. Shanghai, China: Shanghai Scientific \& Technical Publishers (in Chinese).

Lowe, T. M. \& Eddy, S. R. (1997). tRNAscan-SE: A program for improved detection of transfer RNA genes in genomic sequence. Nucleic Acids Research 25, 955-964.

Lu, G. Q., Li, S. F. \& Bernatchez, L. (1997). Mitochondrial DNA diversity, population structure and conservation genetics of four native carps within the Yangtze River, China. Canadian Journal of Fisheries and Aquatic Sciences 54, 47-58.

Lu, C. Y., Sun, X. W. \& Lian, L. Q. (2005). Isolation of microsatellite markers in bighead carp Aristichthys nobilis. Journal of Fishery Science of China 12, 192-196 (in Chinese).

Mabuchi, K., Miya, M., Senou, H., Suzuki, T. \& Nishida, M. (2006). Complete mitochondrial DNA sequence of the Lake Biwa wild strain of common carp (Cyprinus carpio L.): further evidence for an ancient origin. Aquaculture 257, 68-77.

Miya, M., Takeshima, H., Endo, H., Ishiguro, N. B., Inoue, J. G., Mukai, T., Satoh, T. P., Yamaguchi, M., Kawaguchi, A., Mabuchi, K., Shirai, S.M. \& Nishida, M. (2003). Major patterns of higher teleostean phylogenies: a new perspective based on 100 complete mitochondrial DNA sequences. Molecular Phylogenetics and Evolution 26, $121-138$.

Miya, M., Holcroft, N., Satoh, T. P., Yamaguchi, M. \& Nishida, M. (2007). Mitochondrial genome and a nuclear gene indicate a novel phylogenetic position of deep-sea tube-eye fish (Stylephoridae). Ichthyological Research 54, 323-332. 
Murakami, M., Yamashita, Y. \& Fujitani, H. (1998). The complete sequence of mitochondrial genome from a gynogenetic triploid 'ginbuna' (Carassius auratus langsdorfi). Zoological Science 15, 335-337.

National Inspection Bureau for Quality and Technology, People's Republic of China (1999a). National Standard for Silver Carp. GB 17717: 1999 (in Chinese).

National Inspection Bureau for Quality and Technology, People's Republic of China (1999b). National Standard for Bighead Carp. GB 17718:1999 (in Chinese).

Oshima M. (1919). Contributions to the study of freshwater fishes of the island of Formosa. Annals of the Carnegie Museum 12, 169-328.

Peng Z., Wang, J. \& He X. (2006). The complete mitochondrial genome of the helmet catfish Cranoglanis bouderius (Siluriformes: Cranoglanididae) and the phylogeny of otophysan fishes. Gene 376, 290-297.

Ronquist, F. \& Huelsenbeck, J. P. (2003). MrBayes 3: Bayesian phylogenetic inference under mixed models. Bioinformatics 19, 1572-1574.

Saitoh, K., Sado, T., Mayden, R. L., Hanzawa, N., Nakamura, K., Nishida, M. \& Miya, M. (2006). Mitogenomic evolution and interrelationships of the Cypriniformes (Actinopterygii: Ostariophysi): the first evidence toward resolution of higher-level relationships of the world's largest freshwater fish clade based on 59 whole mitogenome sequences. Journal of Molecular Evolution 63, 826-841.

Sambrock, J. \& Russell, D. W. (2001). Molecular Cloning: A Laboratory Manual 3rd edn. New York, NY: Cold Spring Harbor Laboratory Press.

Scribner, K. T., Page, K. S. \& Bartron, M. L. (2001). Hybridization in freshwater fishes: a review of case studies and cytonuclear methods of biological inference. Reviews in Fish Biology and Fisheries 10, 293-323.

Shadel, G. S. \& Clayton, D. A. (1997). Mitochondrial DNA maintenance in vertebrates. Annual Review of Biochemistry 66, 409-435.

Shan, Q., Dong, S., Wu, H. F. \& Taniguchi, N. (2006). Diversity analysis on mtDNA D-loop region of three populations of Aristichthys nobilis. Journal of Fishery Science of China 13, 174-180 (in Chinese).

Tamura K., Dudley, J., Nei, M. \& Kumar, S. (2007). MEGA4: Molecular Evolutionary Genetics Analysis (MEGA) software version 4.0. Molecular Biology and Evolution 24, 1596-1599.

Verigin, B. V., Makeeva, A. P. \& Shubnikova, N. G. (1979). A case of natural hybridization between Hypophthalmichthys molitrix and Aristichthys nobilis (Pisces, Cyprinidae). Zoologicheskii Zhurnal 58, 190-196.

Wang, C. H., Chen, Q., Lu, G., Xu, J. W., Yang, Q. L. \& Li, Si. F. (2008). Complete mitochondrial genome of the grass carp (Ctenopharyngodon idella, Teleostei): insight into its phylogenic position within Cyprinidae. Gene 424, 96-101.

Wu, X. W. (1964). Fishes of Cyprinidae in China, Vol. 1. Shanghai, China: Shanghai Scientific Press (in Chinese).

Xia, D. Q., Yan, H., Wu, T. T., Dong, Z. J., Jian, J. C., Cao, Y. \& Zhang, Y. S. (1996). Study on the population genetic structure of black carp, grass carp, silver carp and bighead carp in Tian-E-Zhou open old course of the Yangtze River. Journal of Fishery Science of China 3,11-18 (in Chinese).

Zhang, D. C. (2002). Study on the genetic diversity of cultivated population of bighead carp (Aristichthys nobilis). Journal of China Three Gorges University (Natural Sciences) 24, 379-381 (in Chinese).

Zhang, S. M., Deng, H. \& Wang, D.Q. (2001). Population structure and genetic diversity of silver carp and grass carp from populations of the Yangtze River system revealed by RAPD. Acta Hydrobiologica Sinica 25, 324-330 (in Chinese).

Zhang, S. M., Wang, D. Q., Deng, H. \& Yu, L. N. (2002). Mitochondrial DNA variation of silver carp and grass carp of middle reaches of the Yangtze River revealed by using PCR-AFLP. Acta Hydrobiologica Sinica 26, 142-147 (in Chinese).

Zhang, X. Y., Yang, J. Q., Zhang, D. C., Deng, F. J., Yu, L. N. \& Fang, Y. L. (1999a). RAPD analysis on Hypophthalmichthys molitrix and Anistchthys noblils. Progress in Biochemistry and Biophysics 26, 469-472 (in Chinese). 
Zhang, X. Y., Zhang, X. Y., Yang, D. S., Yu, L. N., Fang, Y. L., Deng, F. J. \& Liu, S. Y. (1999b). Studies on genetic diversity of bighead carp (Aristichthys nobilis) in the Yangtze River. Journal of Wuhan University (Natural Science Edition) 45, 857-860 (in Chinese).

Zhao, J. L. \& Li, S. F. (1996). Isoenzyme analysis of population diversity of silver carp, bighead carp, grass carp and black carp in the middle and low stream of Changiiang River. Journal of Fisheries of China 20, 104-110 (in Chinese).

Zhu, X. D., Geng, B., Li, J. \& Sun, X. W. (2007). Analysis of genetic diversity among silver carp populations in the middle and lower Yangtze River using thirty microsatellite makers. Hereditas 29, 705-713 (in Chinese). 